\title{
Bioclimatic Conditions: A Forgotten Factor in the Domestic Habitat in the City of Palmira, Colombia
}

\author{
*Luis Manuel Muñoz Cruz, John Jairo Delgado Echeverri, \\ Mauricio Gonzalez Arroyave, Danilo Hernan Bejarano and \\ Oscar Fernando Manrique Florez
}

Published online: 15 January 2018

To cite this article: Luis Manuel Muñoz Cruz, John Jairo Delgado Echeverri, Mauricio Gonzalez Arroyave, Danilo Hernan Bejarano and Oscar Fernando Manrique Florez. (2017). Bioclimatic conditions: A forgotten factor in the domestic habitat in the city of Palmira, Colombia. Journal of Construction in Developing Countries, 22(2): 81-100. https://doi.org/10.21315/ jcdc2017.22.2.6

To link to this article: https://doi.org/10.21315/jcdc2017.22.2.6

\begin{abstract}
This research analyses sustainability issues in six social housing projects in the city of Palmira (South-West Colombia) considering three main components: environmental efficiency, sustainability, and comfort. This research has a mixed character, integrating quantitative and qualitative elements with a descriptive component, to establish parameters that allow the proposal of comprehensive urban development projects, based on the concept of habitat. Additionally, three perspectives were determinant for the development of this research: an architectonic, urban and regional perspective, focused on technical and technological parameters; an environmental perspective, focused on biotic elements; and a cultural and social perspective, considering the population and its relationship with particular spaces.
\end{abstract}

Keywords: Social housing, Sustainable architecture, Urban habitat, Colombia

\section{INTRODUCTION}

Historically, the environment has been a decisive factor for the development of humankind, having a direct influence over comfort and the satisfaction of basic needs. Hence, both climate and weather have always been determining elements when planning and developing habitational spaces. Today, the application and development of weather-efficient design is mandatory for modern architecture, taking into account both urban development and human comfort. Thus, this project aims to identify and characterise issues related to environmental efficiency, sustainability and comfort in urban development and living spaces, focusing on a particular case study i.e. social housing projects in the city of Palmira (South-West Colombia).

\section{Background and Pertinence}

Given Colombia's levels of poverty, homelessness, and internal displacement, among several other social and economic issues, the development of social housing policies has been common during the last decades. The objective of reducing the country's housing deficiency has been addressed through a quantitative, rather than qualitative approach, aiming to grow social housing in numbers while, in some

Antonio Nariño University, COLOMBIA

*Corresponding email: luismuno@uan.edu.co 
cases, failing to fulfil basic parameters of sustainability and comfort. In addition, Colombian weather conditions, which are characteristic of a tropical country, are often ignored when developing social housing projects, and Colombian building policies and regulations lack rigorous controls over quality standards. Hence, this project was proposed keeping in mind the social, political, economic, environmental, and cultural importance of social housing projects in Colombia, as recognising their current issues is mandatory to contribute to the improvement of the living conditions of their inhabitants. However, it is necessary to develop complementary research on this area, proposing conscious and efficient architectonic design, in accordance with comprehensive urban planning.

The city of Palmira was chosen for this particular case study, as its social housing projects have been growing rapidly in recent years without the adequate planning and regulation. This situation generates issues regarding population, environment and urban sustainability, with direct social, economic, and environmental consequences. Hence, this research focuses on the identification and characterisation of the main issues of social housing projects in the city of Palmira from the perspective of sustainable architecture, focusing on three main elements: environmental efficiency, sustainability, and comfort.

Palmira is located in the Valle del Cauca region (South-West Colombia) with an estimate population of 370,000 inhabitants (Departamento Administrativo Nacional de Estadística [DANE], 2007), a total area of $1.162 \mathrm{~km}^{2}$ and an urban area of $23 \mathrm{~km}^{2}$, which is growing considerably fast (Instituto de Estudios Ambientales Universidad Nacional de Colombia [IDEA], 2002). The metropolitan area is divided into 16 districts: districts 1 to 7 form the urban area, and districts 8 to 16 correspond to their rural surroundings (ibid.). Given its location, Palmira's tropical weather varies slightly through the year, with predominantly rainy and sunny seasons, but maintaining a temperature between $18^{\circ} \mathrm{C}$ and $37^{\circ} \mathrm{C}$ (Alcaldía de Palmira, 2012).

\section{Aims and Objectives}

The main objective of this project is to identify and characterise the main issues of social housing projects in the city of Palmira (Valle del Cauca region, SouthWest Colombia) from the perspective of sustainable architecture, focusing on sustainability, environmental efficiency, and comfort.

\section{FRAME OF REFERENCE}

\section{Historical Considerations}

The development of social housing in Colombia was summarised by the Colombian Ministry of Housing in the document "Colombia: One hundred years of housing policies" (Colombian Ministry of Housing, 2014), considering social, demographic, and economic perspectives. The document recognised five periods: Hygienist, Institutional, Transitional, Corporations of savings and housing, and Market and subsidisation of demand.

Hygienist Conception (1918-1942): Several medical organisations in Colombia developed studies about housing in the early 20th century, identifying deficient hygiene conditions related to water and sewage services in working class and low- 
income neighbourhoods. However, the intervention of the government in this situation only started between the 1920s and the 1930s. By 1936, the Colombian government acknowledged the social function of property and following an American model, developed housing projects focused on working class and inhabitants of rural areas to strengthen the national economy by promoting demand and consumption. During this period, rural housing projects emerged.

Institutional Conception (1942-1965): The state intervention allowed the establishment of funding schemes and low-interest credits for housing. The deficient hygiene conditions in housing were regulated by the National Health Institute, influencing the development and planning of the incipient social housing projects. Between 1958 and 1962, the housing policies were focused on the country's economic problems, identifying the proliferation of slums and the lack of private investment as their main problems.

Transitional Period (1965-1972): The institutional intervention in social housing was fostered by the establishment of the National Savings Fund in 1968 and the High Council of Housing and Urban Development in 1969. These institutions promoted programmes of subsidisation, particularly for low-income families. During this period, the government recognised social housing not only as a housing matter, but also as a platform to improve the population's productivity.

Corporations of Savings and Housing (1971-1990): This period is defined by the intervention of private entities namely banks and private building companies as the main institutions for funding housing projects. During these years the basic income was defined as the measuring standard for housing prices and housing subsidies.

Market and Subsidisation of Demand (1990-2002): The state actively participated in the housing market without competing against the private sector, by adopting a role of facilitator rather than a commercial one. This situation was the result of a negative balance in national housing, which triggered the state intervention through supervision and administration.

In recent years (2010-2014), the Colombian government implemented a policy entitled "Prosperity for Everyone" in the National Development Plan, which addresses the subject of social housing and housing in general through the formulation of quantitative goals in terms of construction.

The previously mentioned periods evidence the almost exclusively economic scope adopted by the Colombian government regarding social housing and its issues. This perspective follows a quantitative perspective, relegating qualitative approaches and undermining or even ignoring the importance of regulation and control policies concerning technical characteristics and the occupants' welfare, which includes the role of cultural and environmental conditions.

\section{Legal Framework}

In the international context, the access to housing and its relationship with welfare and dignified living is established in Article 25 of the Universal Declaration of Human Rights (United Nations General Assembly, 1948) and Article 11 of the International Covenant on Economic, Social, and Cultural Rights (United Nations General 
Assembly, 1966). For the particular case of Colombia, the National Constitution declares in Article 51 that the State has to promote social housing policies, giving priority to low-income families, to pursue human dignity (Republic of Colombia, 1991). More specifically, Law 1537 (Congress of the Republic of Colombia, 2012) establishes and regulates the parameters for urban development and housing projects, specifically addressing social housing in Articles 2, 5, 12, 15, and 46. The subjects discussed in this law include building permissions, budgets, funding schemes and resources, critical population, assignment of space, and quality standards for living conditions in built spaces.

\section{Theoretical Framework}

Influence of Climate and Weather Conditions over Human Development: Astronomy was one of the first scientific interests of humankind, as comprehending the lunar and solar cycles allowed the understanding of weather processes that influenced vital subsistence practices such as fishing and agriculture. As human knowledge grew on this area, several other practices started acknowledging the importance of astronomy and its influence over the weather, such as architecture. In today's architecture, comfort and sustainability are directly related to environmental conditions, and the habitational needs ought to be supplied in accordance with the conditions of the buildings' surrounding areas. Consequently, the influence of weather over habitational spaces has a direct effect over public health, welfare, and general social and economic stability.

Housing, Human Settlements and Quality of Life: This topic is discussed in the Habitat II Report by the United Nations (United Nations General Assembly, 1996), in which is established that:

"The quality of life of all people depends, among other economic, social, environmental and cultural factors, on the physical conditions and spatial characteristics of our villages, towns and cities. City lay-out and aesthetics, land-use patterns, population and building densities, transportation and ease of access for all to basic goods, services and public amenities have a crucial bearing on the liveability of settlements."

Thus, the adequate establishment of human settlements requires a convergence between the people and their surroundings, based on sustainable, well planned and accessible plans, considering space, society and environment.

Social Housing: The concept of social housing involves state policies that settle parameters for housing, and regulate the establishment of settlements intended to aid low income families. As it was previously stated, this kind of initiatives can be traced in Colombia back to 1918; however, the term was officially applied in 1966. Three main agents can be recognised regarding the proposition and execution of social housing projects; the first one is the state, which regulates their development and grants financial support. The second is the private sector, mainly formed by banks and building companies, which executes the housing projects and provides loans for the buyers. Lastly, the third agent corresponds to the residents, as they not only acquire the houses, but also modify and customise them, sometimes without following the adequate structural regulations. 
Urban Habitat: The concept of urban habitat refers to the physical space in which many people live, with a minimum of five thousand inhabitants, and at least three quarters of them work in industrial, commercial or service sectors (Colombian Ministry of Environment and Territorial Development, 2012). However, to develop a comprehensive approach to this concept, environmental factors need to be considered; this conception of urban habitat linked to an environmental context takes into account the sun path, access to water, winds, humidity, rain, vegetation, and human life in general.

Sustainability: The concept of sustainability has had several interpretations through history. During the 1960s, it was associated with environmentalism; however, the participation of financial interests resulted in a broad conception of the concept, which benefits all the parts involved: sustainability became an idea associated to the efficient and convenient maintenance and durability of diverse projects, with the main principle of finding solutions to current needs, that could also solve the needs of future generations. Under this conception the design of dwelling takes place keeping in mind the reduction of building and maintenance costs, the preservation of the environmental conditions in which the building takes pace, and the efficient consumption of natural and renewable resources; generating environmental, social, and economic advantages (Gallopin, 2003).

Sustainable Architecture: According to Garzón (2007), this model is based on the principle of pursuing the users' welfare through hydro-thermic comfort while integrating the architectonic object with its natural context. Sustainable architecture is a relatively new tendency in housing development, which integrates the environmental resources while reducing energy consumption. Hence, sustainable architecture can be seen as a suitable tool for the development of habitational spaces, focusing on the adequate use of materials, the optimisation of energy, the use of renewable resources, and the integration of humankind with its environment in a more equilibrated ecosystem. Accordingly, the thoughtful consideration of four elements is determinant for sustainable architecture and sustainable urban planning: (1) using building materials convergent with geographic and cultural contexts; (2) reducing maintenance costs; (3) using water and energy efficiently; and (4) employing renewable resources.

Comfort (Housing): This concept is related to adequate living conditions in built environments and living spaces, giving particular importance to thermic and lighting parameters, and keeping in mind that both light and temperature are directly influenced by external factors.

\section{LITERATURE REVIEW}

The existing literature on this subject shows how the topic of social housing in Colombia has been discussed from different approaches; however, the most common perspectives are political and economic.

The Institute of Housing and Urbanism from the Pontifical Xavierian University (Instituto Javeriano de Vivienda de Interés Social [INJAVIU], 2002) developed two studies focusing on the living conditions of low income families in Bogotá (Colombia), focusing on housing quality. These investigations concluded that housing projects for 
low income families are developed from a mainly economic perspective, without taking into account cultural and social factors. As a result, these living spaces feature urbanistic, architectonic, and hygienic issues that affect their residents.

Gonçalves (2005) summarised the main factors to be considered when developing sustainable architectonic projects in Ibero-American countries, emphasising on the use of renewable energy according to the needs and resources typical from each country, and discussing topics such as materials, weather, thermal conditions of the buildings, technologies for the efficient use of energy and the overall design of comprehensive habitational spaces.

The Colombian Ministry of Housing (2014) summarised the evolution of housing policies in Colombia through the 20th century and the early 21 st century, focusing on institutional processes and the role of government institutions. In addition, The Colombian Ministry of Environment and Territorial Development (2012) presented a set of guidelines for urban planning and building, focusing on sustainable development and environmental issues related to health, life quality, urban environment, and sustainability. This document suggests four main axes to consider: energy, water, construction materials, and soil.

Escallón (2011) studied the main issues of social housing in Colombia, focusing on comprehensive management, funding, pertinence, planning, and execution. One of the main problems identified by the author was the lack of proposals dignifying the built space through design.

Lastly, Susunaga (2014) discusses sustainable building in social housing projects through international standards, from Australia, Japan, the United States, and the United Kingdom, regarding functionality, impact on the surrounding area, and efficient use of renewable energy. The study shows that sustainable social housing projects are economically and technically feasible, and their development depends on the establishment of adequate policies.

\section{METHODOLOGY}

This study was developed by the research group City, Environment and Popular Habitat, from the Faculty of Arts and the Architecture Programme at the Antonio Nariño University (Colombia). This topic follows a research scope established by the university in 2012, which studies urban-related topics from three perspectives: (1) an architectonic, urban and regional perspective, focused on technical and technological parameters; (2) an environmental perspective, focused on biotic elements; and (3) a cultural and social perspective, which deals with population and relationship processes developed within specific spaces and territories. This project is part of a larger scheme, which aims to study and propose models to improve social housing projects in the city of Palmira, Colombia; hence, this research is based on a descriptive focus, joining theoretical and empirical approaches to the studied topic.

Keeping in mind this project's main objective, which relies on the identification and characterisation of the main issues of social housing projects in the city of Palmira (Valle del Cauca Region, South-West Colombia), from the perspective of sustainable architecture, focusing on environmental efficiency, sustainability, and comfort, three main components have been determinant to its accomplishment. 
The first one is the general characterisation of the housing issues in the city of Palmira. This process relies on a contextual description that follows three axes: (1) the relevant characteristics of the city regarding this topic; (2) a summary of external factors influencing it, such as policies and private initiatives; and (3) a specific characterisation of defined and particular habitational problems. These steps were developed through a territorial approach, consulting official accounts including the city's Plan for Territorial Organisation (Plan de Ordenamiento Territorial [POT]), and the database from the System for the Selection of Beneficiaries for Social Programs (SISBEN, by its Spanish acronym) among others.

The second component established the general guidelines to propose possible solutions to the current housing problems in the city. This was possible through the analysis of opportunities and current issues of urban management and the detailed description of the studied examples. Lastly, the third component was based on coding and summarising the gathered data to set up a comprehensive database about the city's housing needs, as well as guidelines and recommendations for future projects.

The previously explained three components were linked to three identifiable methodological stages, which converged in a complementary manner to connect all the components and the research objectives coherently. The three stages were:

1. Proposal: Identify the primary sources (residential areas and houses for the general and specific samples) and review of theoretical accounts, policies, and official regulations concerning them (social housing in Colombia, specifically in the city of Palmira).

2. Data Collection: Keeping in mind the three categories of analysis (environmental efficiency, sustainability, and comfort), the primary data was gathered by employing photographic and thermographic cameras, sound level meters, hygrometers, and heliodons.

3. Data Analysis: The gathered data was processed and confronted with theoretical accounts, policies, and the social, cultural, and environmental backgrounds of each neighbourhood. This stage provided a comprehensive set of conclusions, which can be used in further research when proposing more sustainable, comfortable, and accessible social housing projects in Palmira.

Currently, there are 21 finished social housing neighbourhoods in Palmira; the main sample was obtained after choosing 6 of them, located in the districts 1, 2, 3, 6, and 7. The chosen neighbourhoods were: Plaza Campestre, Samanes, Bosques de Morelia, Parques de la Italia, El Sembrador, and Poblado Comfaunión. This sample aims to be representative, as the chosen neighbourhoods feature an average size and population for this type of residential projects; however, since they are located in different areas within the city, potential differences between their urban configuration and distribution/management of public spaces and green areas were easier to identify. Furthermore, a considerable chronological difference between the neighbourhoods' establishment was considered, allowing to identify both original designs in recently developed social housing projects (finished in the decade of 2010), and extensive modifications in the older ones (finished in the decade of 1980). 
Additionally, 24 houses were chosen as illustrative sample, suitable for a detailed architectonic and structural analysis: four houses from each neighbourhood, each one of them facing a different cardinal point (north, south, east, and west).

To develop the sampling process, four methodological tools were chosen (Table 1):

1. Journal: A brief description of each of the visited residential areas, outlining some of its general characteristics. The journal features photographs and environmental data including wind, temperature, and sunlight.

2. Maps: Maps of the city, showing the location of each residential area and its detailed blueprints, depicting the urban configuration and the configuration of public space.

3. Interviews: Short structured interviews to several inhabitants of the neighbourhoods and the occupants of the 24 houses from the illustrative sample, transcribed, and summarised. These interviews were focused on comfort, dwelling modifications, and access to public spaces; serving as a complement to the architectonic and urban analysis performed by the researchers.

4. Coding Format: The purpose of this format was gathering and summarising basic information concerning the urbanistic and architectonic features of the sample, arranging and complementing the results from the previous four methodological tools. The format was divided in five components (Table 2):

A. Residential Area Identification: Seven items, including name, location, and general information about the building company.

B. Urban Configuration: Twelve items, including number of blocks, size of blocks, original height of the houses, original number of floors, total built area, and specific structural details.

C. Structural Configuration: Twenty-five items describing in detail the structural and architectonic features and characteristics of the 24 houses chosen for the illustrative sample.

D. Configuration of Public Space: Eight items, including the number and size of vehicle roads, open spaces, pedestrian ways, and sport venues/ facilities.

E. Additional Sources: Description of additional sources of information, in the necessary cases, not including the chosen methodological tools.

Table 1. Methodological Role and Resulting Data from the Chosen Tools

\begin{tabular}{lll}
\hline Tool & Function Towards Sample & Resulting Data \\
\hline 1. Journal & $\begin{array}{l}\text { Approaching, describing and } \\
\text { measuring }\end{array}$ & Quantitative and Qualitative \\
2. Maps & $\begin{array}{l}\text { Identify location, configuration } \\
\text { and surroundings } \\
\text { Qualitative description }\end{array}$ & Qualitative \\
3. Interviews & $\begin{array}{l}\text { Summarise and complement } \\
\text { 9athered information }\end{array}$ & Qualitative \\
4. Coding format & Quantitative and Qualitative \\
\hline
\end{tabular}


Table 2. Itemisation of the Coding Format

\begin{tabular}{|c|c|c|c|}
\hline \multirow{5}{*}{$\begin{array}{l}\text { Coding } \\
\text { Format }\end{array}$} & & $\begin{array}{l}\text { Residential area } \\
\text { identification }\end{array}$ & $\begin{array}{l}\text { Neighbourhood general information ( } 3 \text { items) } \\
\text { Building company information ( } 4 \text { items) }\end{array}$ \\
\hline & B. & Urban configuration & $\begin{array}{l}\text { Characteristics of blocks ( } 7 \text { items) } \\
\text { General features of houses ( } 5 \text { items) }\end{array}$ \\
\hline & C. & $\begin{array}{l}\text { Structural } \\
\text { configuration }\end{array}$ & $\begin{array}{l}\text { Detailed structural features of houses: areas ( } 12 \text { items), } \\
\text { measures ( } 11 \text { items), and materials ( } 2 \text { items) }\end{array}$ \\
\hline & D. & $\begin{array}{l}\text { Configuration of } \\
\text { public space }\end{array}$ & $\begin{array}{l}\text { Public venues and facilities ( } 3 \text { items), green areas ( } 3 \\
\text { items), and roads ( } 2 \text { items) }\end{array}$ \\
\hline & E. & Additional sources & List of additional sources \\
\hline
\end{tabular}

\section{RESULTS}

\section{Neighbourhood 1 - Plaza Campestre (blueprint of the neighbourhood is shown in Figure 1)}

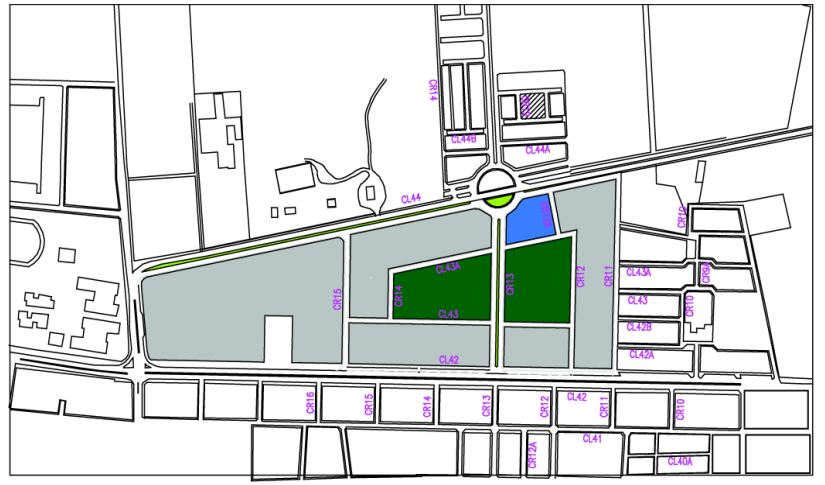

Figure 1. Urban Configuration, Neighbourhood 1

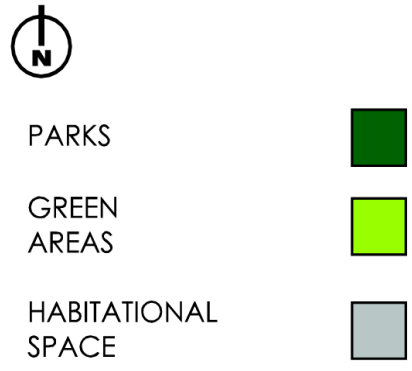

STREETS

nOMENCLATURE CL CR

LOCATION: North-East, District 2.

URBAN CONFIGURATION: The residential area features an irregular shape, and therefore, the distribution of blocks is also irregular. Two important streets cross through this neighbourhood: 19th and 42nd; however, several of the streets inside the neighbourhood have opposite directions in relation to the city's normal flow of vehicles, generating mobility issues.

STRUCTURAL CONFIGURATION: Two-floor houses with a backyard.

BUILDING TECHNIQUE: Structural masonry.

STRUCTURE MATERIALS: Cored clay bricks and concrete mortar.

ORIGINAL ROOFING MATERIALS: Fibre cement with steel structure.

OPEN SPACES AND ENVIRONMENTAL ANALYSIS: The neighbourhood features one main park, which covers $18 \%$ of the neighbourhood's total area. Currently, this park lacks any full-grown trees, and the main species, in growing stage, are common palm trees and Pithecellobium dulce (commonly referred as Chiminango), which grows up to 15 meters. 
The houses facing East should develop elements of sunlight mitigation, such as trees, in the cases of the houses facing the main open area, as the façades are exposed to direct sunlight during the morning, rising considerably the houses' temperature. Consequently, the houses facing west should develop even stronger elements of sunlight mitigation, as they are affected by direct sunlight during the afternoon hours; trees are also a suitable option for the ones facing the main open area.

The relative proximity of this residential area to the Central-Andes mountain chain by the west side provides winds from the North-East. These wind currents could be used to lower the houses' inner temperatures through cross-ventilation. Figure 2 presents a photograph of an average house from the neighbourhood.

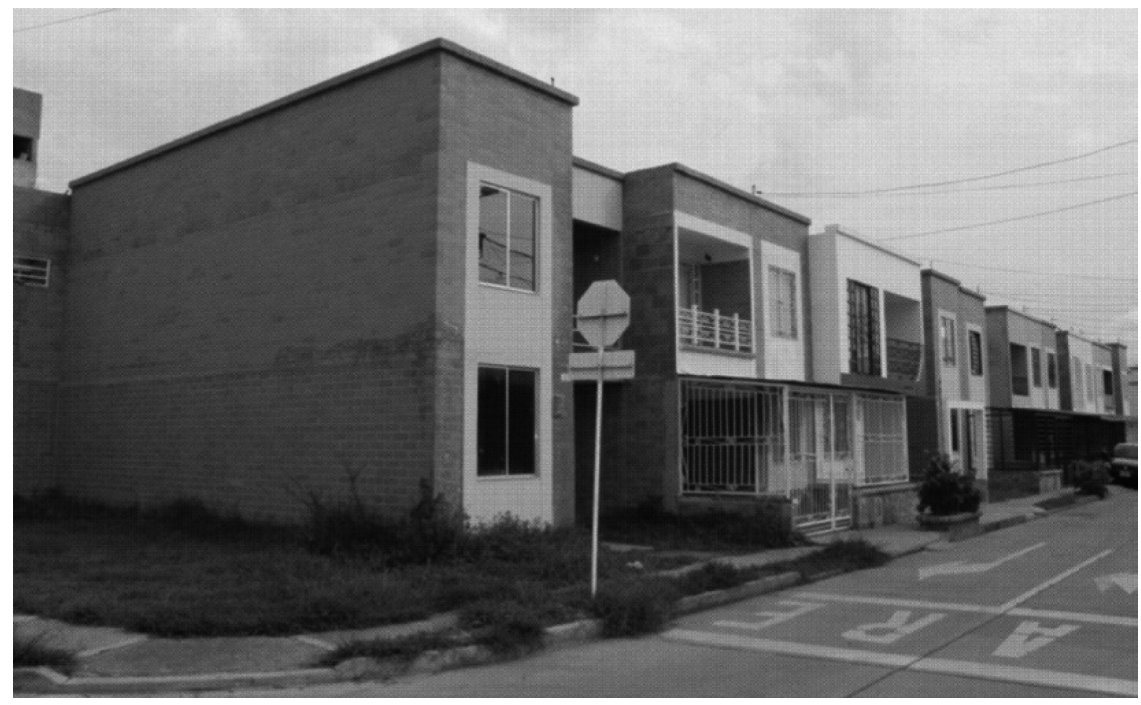

Figure 2. Typical Structural Configuration from Neighbourhood 1

Neighbourhood 2 - Samanes (blueprint of the neighbourhood is shown in Figure 3)

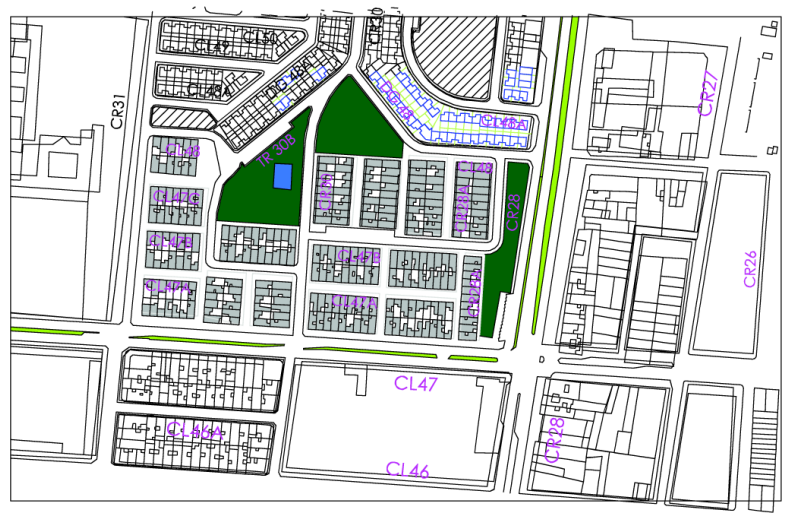

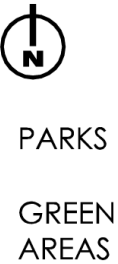

HABITATIONAL SPACE

\section{STREETS} NOMENCLATURE
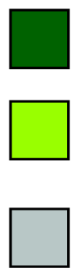

CL CR

Figure 3. Urban Configuration, Neighbourhood 2 
LOCATION: North-West, District 2.

URBAN CONFIGURATION: This area is composed by 17 irregular blocks. Three considerably important streets cross the neighbourhood (31st, 28th, and 47th); additionally, $70 \%$ of the roads are pedestrian-only.

STRUCTURAL CONFIGURATION: The houses were originally delivered unfinished; thus, their modification is evident.

BUILDING TECHNIQUE: Structural masonry.

STRUCTURE MATERIALS: Cored clay bricks and concrete mortar.

ORIGINAL ROOFING MATERIALS: Fibre cement with steel structure.

OPEN SPACES AND ENVIRONMENTAL ANALYSIS: Three main parks form the neighbourhood's open spaces. The nourished arborisation, both in quantity and variety, mitigates the effect of direct sunlight in several houses; however, this feature does not benefit the whole neighbourhood. Furthermore, given the proximity to the Andes Mountain chain, the winds from East to West are frequent, and this element is commonly not employed to provide solutions for high temperature issues. Figure 4 presents a photograph of an average house from the neighbourhood.

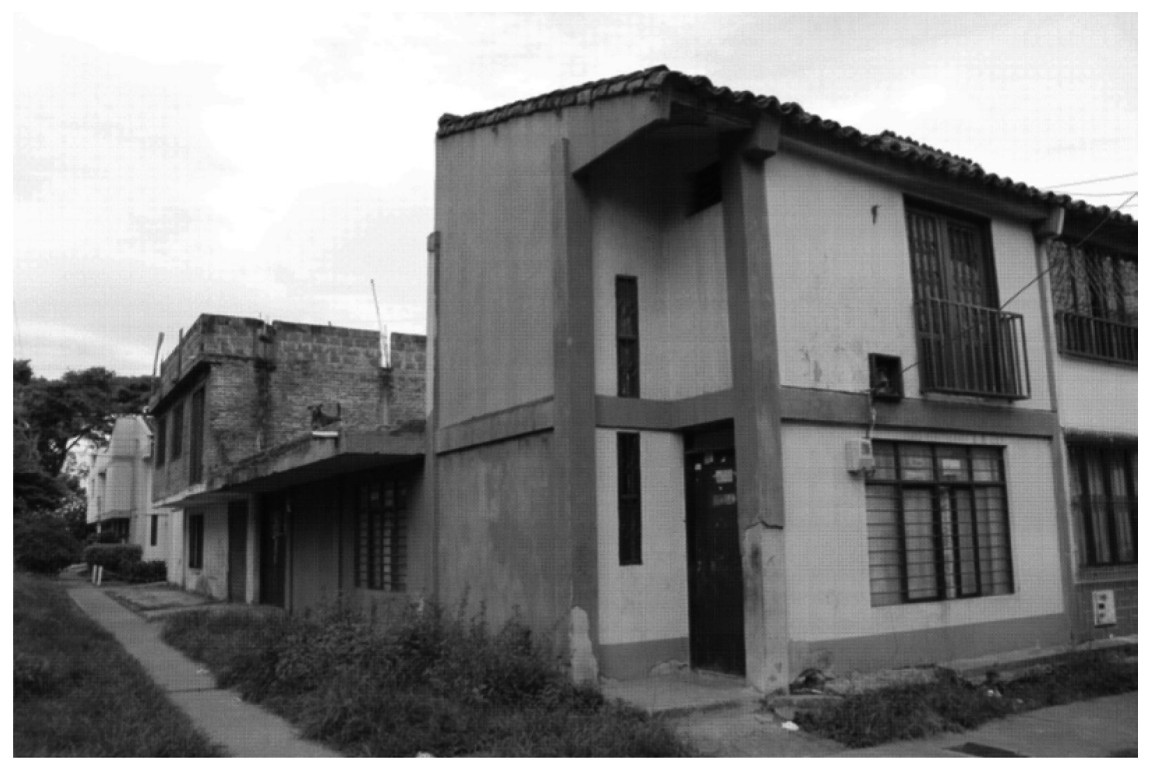

Figure 4. Structural Configuration from Neighbourhood 2, Evidencing Common Structural Modifications 
Neighbourhood 3 - Bosques De Morelia (blueprint of the neighbourhood is shown in Figure 5)
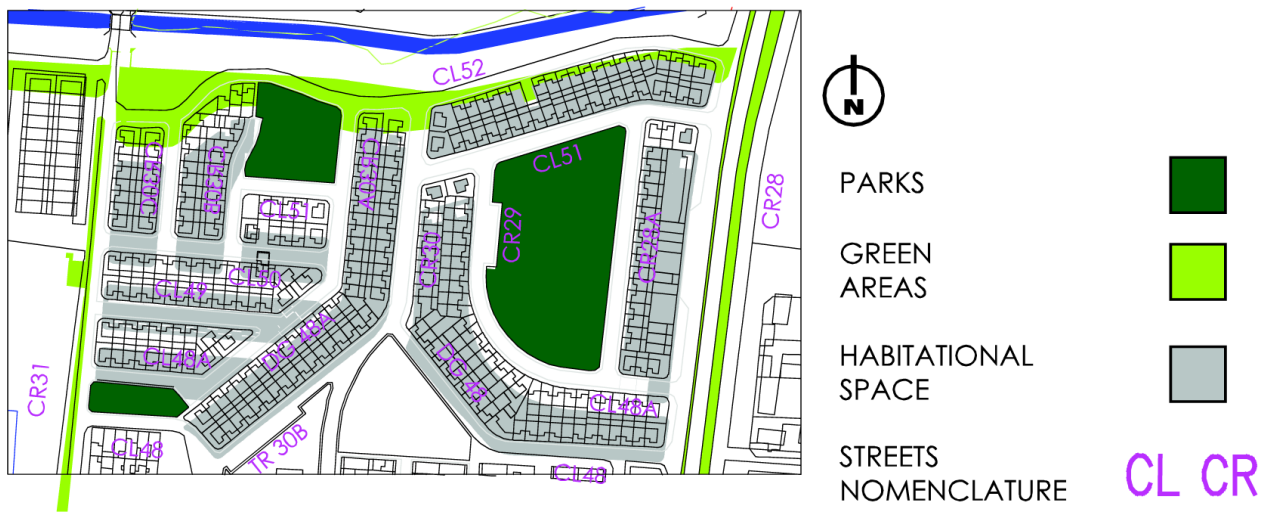

Figure 5. Urban Configuration, Neighbourhood 3

LOCATION: North, District 2.

URBAN CONFIGURATION: This area features an irregular configuration. Since the 28th street crosses this area, an important highway that connects the north and the south of the country, several houses facing it have been adapted for commercial purposes.

STRUCTURAL CONFIGURATION: Two-floor houses with a backyard. The modification of most of the houses is evident; mostly as a result of the previously mentioned commercial activity.

BUILDING TECHNIQUE: Structural masonry.

STRUCTURE MATERIALS: Cored clay bricks and concrete mortar.

ORIGINAL ROOFING MATERIALS: Fibre cement with steel structure.

OPEN SPACES AND ENVIRONMENTAL ANALYSIS: Three main open spaces with abundant, varied, and mature vegetation are featured in this area, creating a barrier that blocks the direct effect of sunlight over the neighbouring houses, providing thermic comfort. One of these areas surrounds the Mirriñao Creek, which crosses the neighbourhood through the north side, and is categorised as protected area; in addition, several green paths have emerged around the river. Figure 6 presents a photograph of an average house from the neighbourhood. 


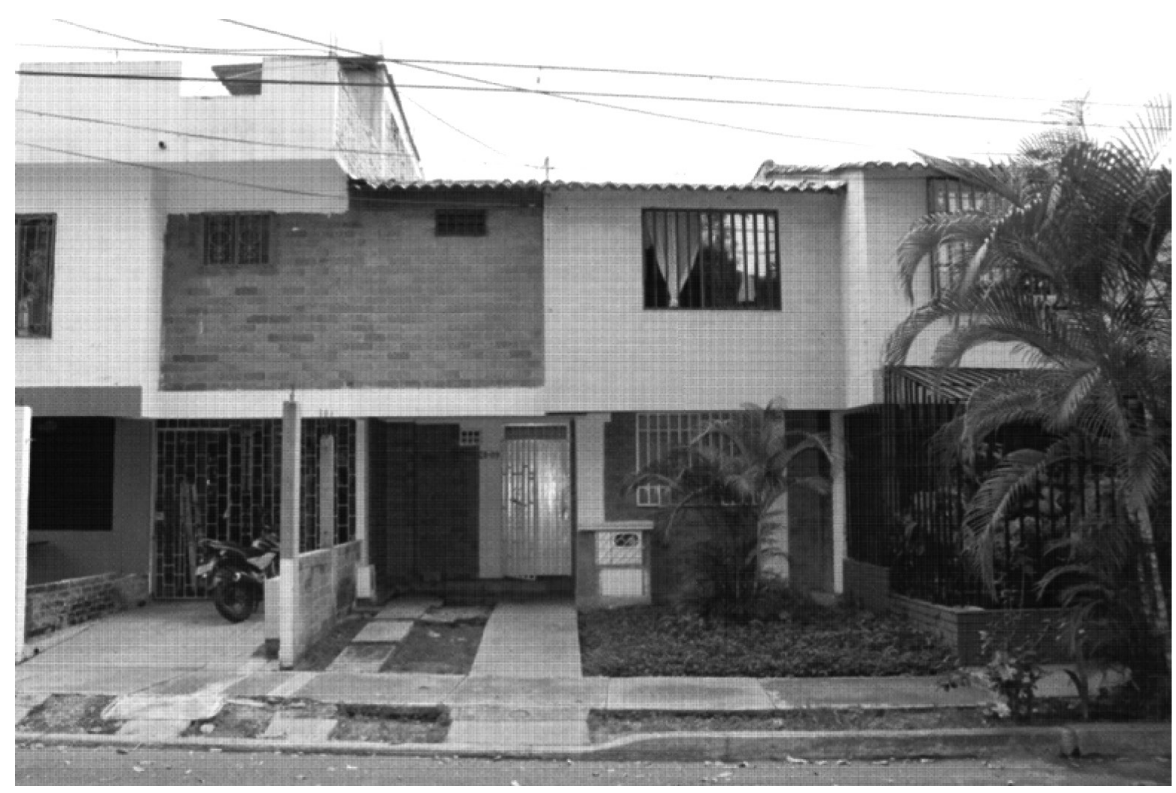

Figure 6. Typical Structural Configuration from Neighbourhood 3

\section{Neighbourhood 4 - Parques De La Italia (blueprint of the neighbourhood is shown in Figure 7)}
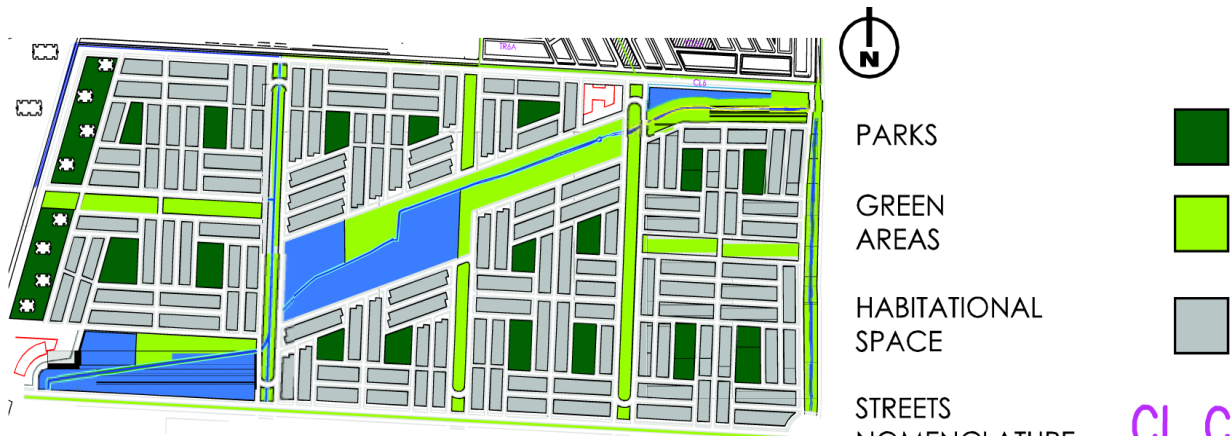

AREAS

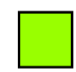

HABITATIONAL

SPACE

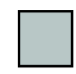

STREETS

NOMENCLATURE

CL CR

Figure 7. Urban Configuration, Neighbourhood 4

LOCATION: South, District 7.

URBAN CONFIGURATION: Regular, with regular blocks.

STRUCTURAL CONFIGURATION: Two-floor houses with a concrete backyard.

BUILDING TECHNIQUE: Structural masonry.

STRUCTURE MATERIALS: Cored clay bricks and concrete mortar.

ORIGINAL ROOFING MATERIALS: Fibre cement with steel structure.

OPEN SPACES AND ENVIRONMENTAL ANALYSIS: The Barrancas Creek, which is a protected area, crosses the neighbourhood, providing its largest open space. Fourteen additional small open spaces can be found around the residential 
area; however, there is no evidence of any planned intervention in these areas. Additionally, given the blocks' orientation, most of the houses are affected by direct sunlight during most of the day, without any elements of mitigation.

The high temperatures inside the houses, as a result of the direct sunlight, could be diminished by taking advantage of the wind currents, flowing from NorthWest and North-East to South; however, this alternative was not implemented in the houses' original design. Figure 8 presents a photograph of an average house from the neighbourhood.

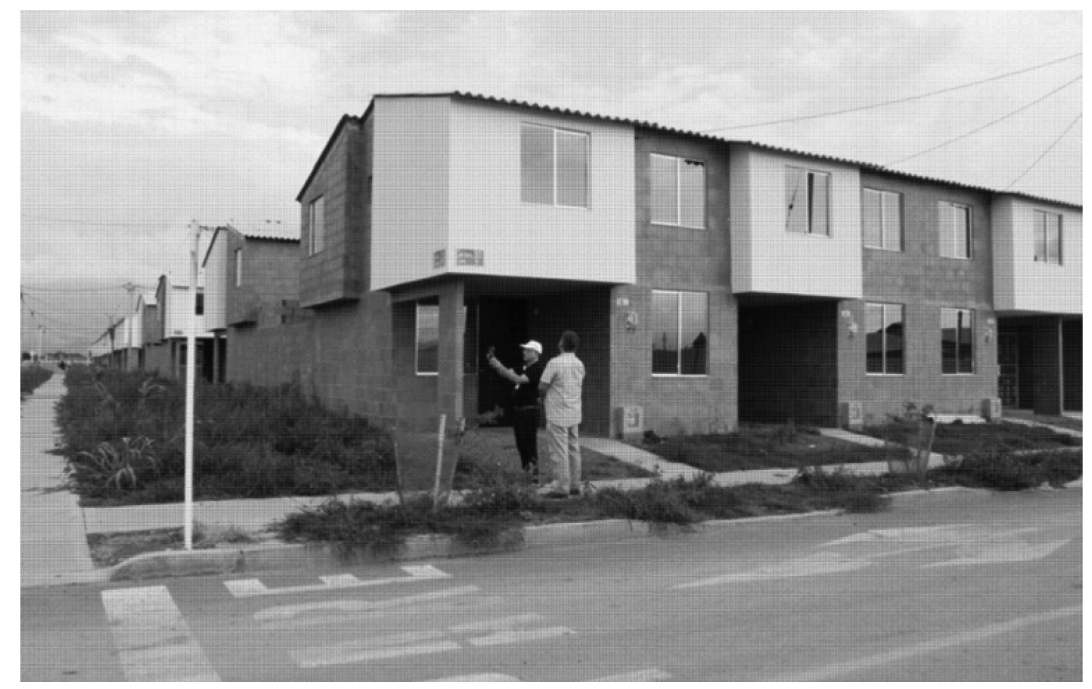

Figure 8. Typical Structural Configuration from Neighbourhood 4

Neighbourhood 5 - Poblado Comfaunión (blueprint of the neighbourhood is shown in Figure 9)

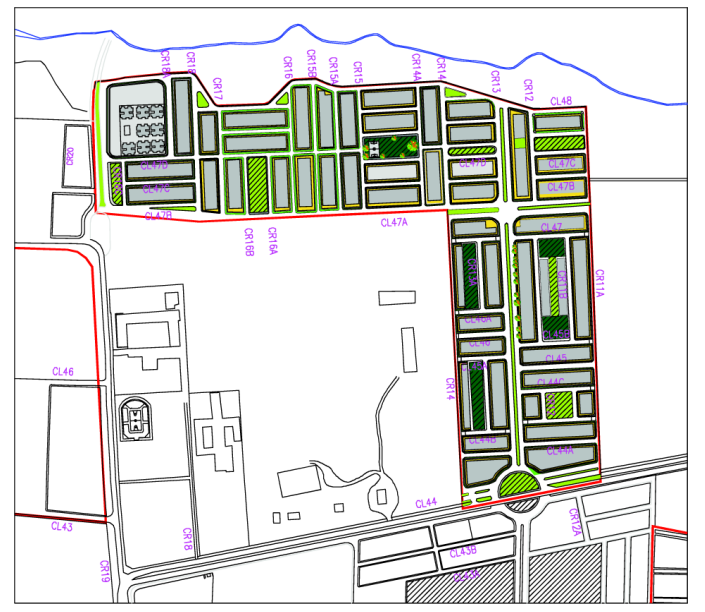

$$
\begin{aligned}
& \text { PARKS } \\
& \text { GREEN } \\
& \text { AREAS }
\end{aligned}
$$

HABITATIONAL

SPACE

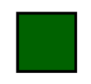

STREETS

NOMENCLATURE

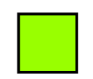

Figure 9. Urban Configuration, Neighbourhood 5 
LOCATION: North-East, District 2.

URBAN CONFIGURATION: Regular. The neighbourhood limits with the 44th street, which is one of the main exits to Palmira's rural area.

STRUCTURAL CONFIGURATION: Two-floor houses with a concrete backyard. Most of them have been modified by the owners, in several cases by adding more floors.

BUILDING TECHNIQUE: Structural masonry.

STRUCTURE MATERIALS: Cored clay bricks and concrete mortar.

ORIGINAL ROOFING MATERIALS: Fibre cement with steel structure.

OPEN SPACES AND ENVIRONMENTAL ANALYSIS: The residential area features 11 open spaces; in these areas, the vegetation is considerably assorted, including several tree species. However, the number and distribution of trees is not sufficient to protect the houses against the direct sunlight. Figure 10 presents a photograph of an average house from the neighbourhood.

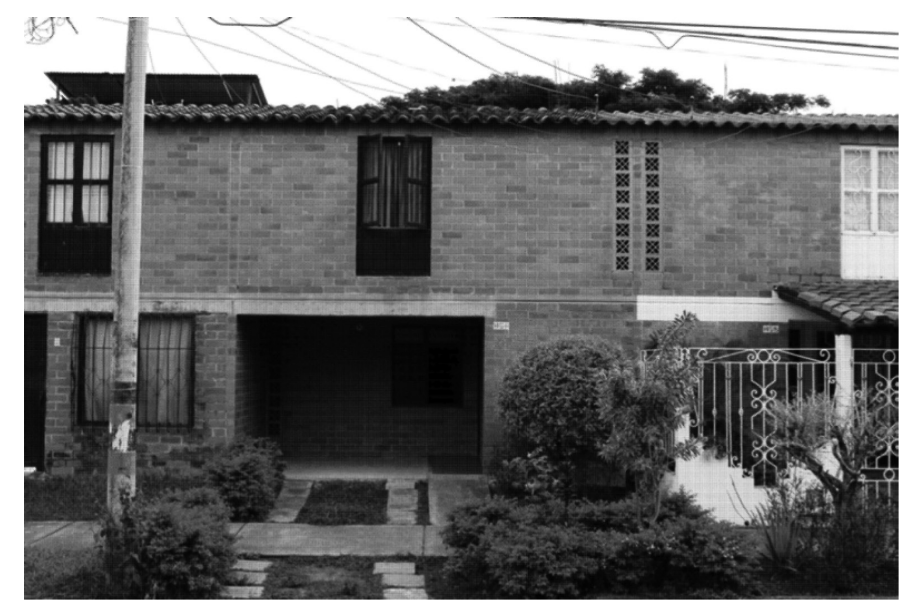

Figure 10. Typical Structural Configuration from Neighbourhood 5

\section{Neighbourhood 6 - El Sembrador (blueprint of the neighbourhood is shown in Figure 11)}

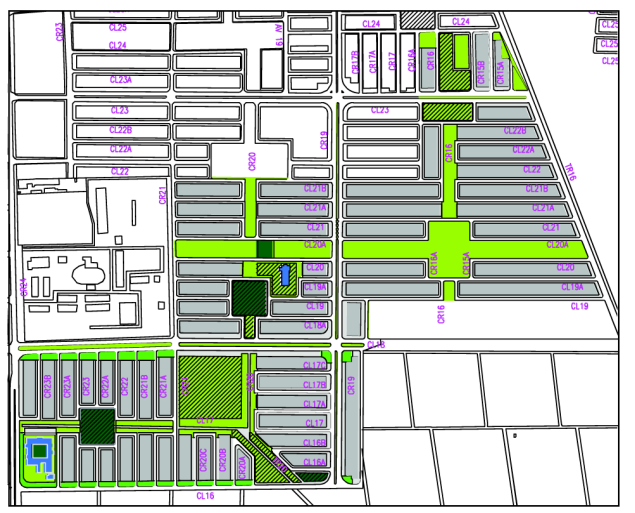

N

PARKS

GREEN

AREAS

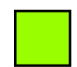

HABITATIONAL

SPACE

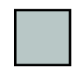

STREETS

nOMEnClature CL CR

Figure 11. Urban Configuration, Neighbourhood 6 
LOCATION: South, District 7.

URBAN CONFIGURATION: Regular.

STRUCTURAL CONFIGURATION: The original design featured single-floor houses; however, most of them have been considerably modified, including additional floors in several cases.

BUILDING TECHNIQUE: Structural masonry.

STRUCTURE MATERIALS: Cored clay bricks and concrete mortar.

ORIGINAL ROOFING MATERIALS: Fibre cement with steel structure.

OPEN SPACES AND ENVIRONMENTAL ANALYSIS: From the sample, El Sembrador features the largest open space area, with 17 individual open spaces; however, these areas lack the adequate intervention to set them up for adequate public use. The houses facing the 16th street are protected from the direct sunlight due to the abundance of trees on the pedestrian path parallel to the street; however, this feature is not common in the rest of the neighbourhood, as most of the houses remain exposed to the sun. Figure 12 presents a photograph of an average house from the neighbourhood.

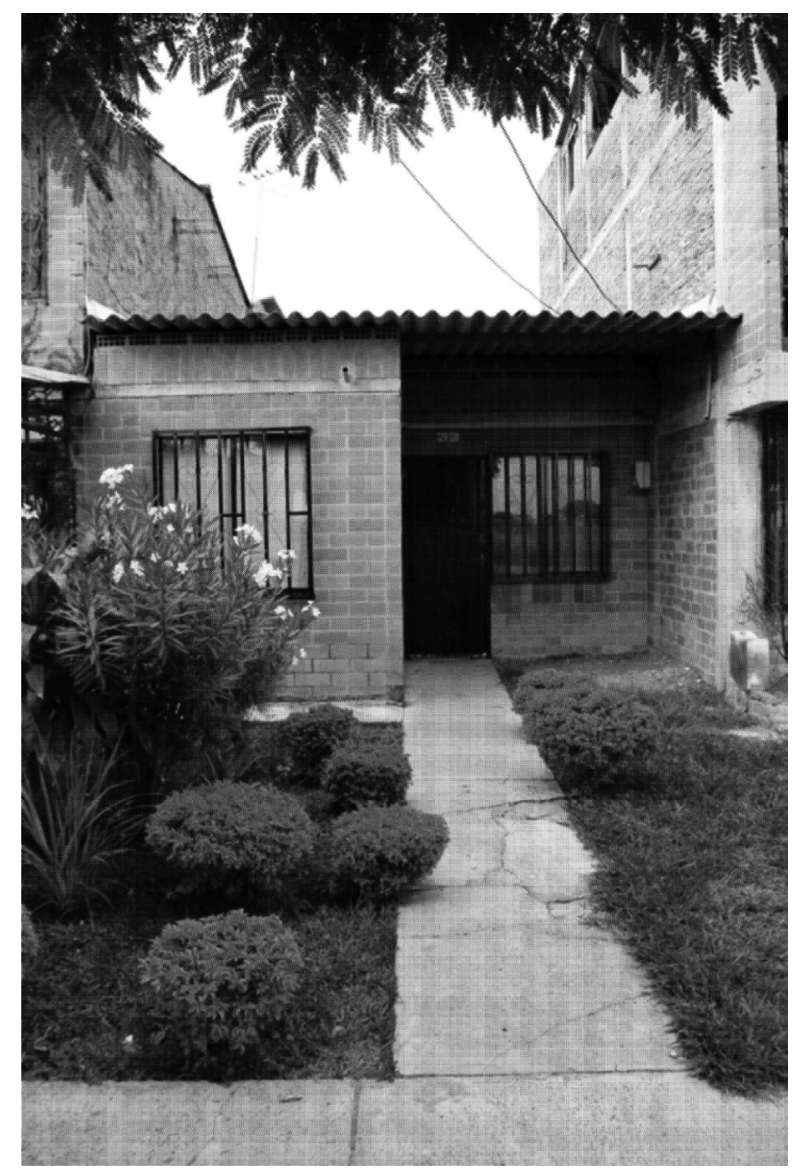

Figure 12. Original Structural Configuration from Neighbourhood 6, Showing Structural Modifications in the Neighbouring Houses 


\section{Tendencies and Convergences}

1. The six chosen residential areas feature ring roads and schools, providing solutions for mobility and basic education needs.

2. Protection against sunlight, either through vegetation or architectonic intervention, is uncommon.

3. All the studied neighbourhoods have open spaces; however, the lack of planning and comprehensive intervention results in the misappropriation of these areas.

4. The houses from the sample have regular access to basic services: energy supply, sewage system, water, gas, internet, telephone, and satellite or cable television.

5. Given its low cost and accessibility, all the studied houses share the same building technique and materials in the original design. This decision can be related to parameters of efficiency and profit.

6. The modification of the houses' original design is considerably common. In several cases, these modifications include changes in the houses' main structural characteristics.

7. Environmental Efficiency: Overall, the studied sample lacks an environmentallyefficient design. An example of this situation is the tendency of not taking advantage of the constant availability of sun and wind to optimise the energy consumption and regulate the high temperatures.

8. Sustainability: The use of regular building materials and the lack of comprehensive processes of arborisation and landscaping, in addition to the previously mentioned inefficient use of energy, demonstrates that these projects are inherently not sustainable.

9. Comfort: the studied habitational spaces present several issues regarding temperature, ventilation, and lighting. Most of these inconveniences could be solved by developing comprehensive architectonic designs that take advantage of the environmental conditions.

10. Overall, the analysed residential areas do not feature considerable innovations in their design. In addition, if the identified problems are replicated in future social housing projects, the general characteristics of Palmira's urban area could be influenced in a negative way.

\section{CONCLUSIONS}

Dwelling plays a decisive role in people's life quality, being directly related to access to services and welfare. Additionally, houses represent the main investment and the most important assets in medium and low-income families in Colombia. However, the Valle del Cauca region, and for this particular case, the city of Palmira, shows a considerable housing deficit among low-income families both in quantitative terms (lack of dwelling and homelessness) and qualitative terms (dilapidated houses and problems with access to basic services). 
Despite being characterised both quantitatively and qualitatively, Colombia's housing deficit has been historically addressed through a small number of standardised variables, without considering the relationship between the social housing projects and their surroundings as their main guideline and direct support. For this reason, it is crucial to consider the notion of Habitat to develop a comprehensive approach to the idea of housing. By applying the conception of habitat, it is possible to plan, evaluate, and execute public policies that aim to apply housing as a solution for complex issues, including extreme poverty and social exclusion. This notion allows an approach to dwelling both as living space and as a dynamic segment of its surroundings, contemplating elements such as access, sustainability, and cohesion.

Future social housing policies in Colombia should consider a more extensive and comprehensive set of variables, measures and patterns, in addition to meticulous regulations, and aligned with environmental laws and policies, which currently are mainly focused on the transportation, storage, and manufacturing of building materials (Unidad de Planeación Minero Energética [UPME], 2016). In addition, the climate conditions inherent to each city should be explored carefully, using them as guidelines for comprehensive designs and differentiated architectonic solutions, as the current conditions are detrimental to hydro-thermic comfort.

The considerably large execution of housing projects in Palmira, and particularly, social housing projects, has several positive outcomes regarding the economy and the housing deficit; however, given the current aims and standards of these initiatives, they can potentially generate social and urban issues in the near future. In response to this, the habitat perspective allows a comprehensive planning, taking into account environmental, economic, social, architectonic, and cultural components, and allowing a comprehensive understanding of the city and the diverse roles of its inhabitants.

Currently, the city of Palmira needs an estimate of 4,000 additional houses for low-income families; furthermore, several neighbourhoods are allocated in marginal and risk areas, which need urgent intervention. However, the lack of studies focusing on soil management, land distribution, and adequate urban development in social housing projects, generates inefficient and ineffective solutions, which interfere with the right development of housing policies. The deficiency of information regarding the current living conditions and urbanistic/architectonic issues of social housing neighbourhoods in Colombia represents one of the main obstacles for the formulation of efficient and comprehensive social housing policies and the adjustment of flaws in already finished housing projects.

Despite the relatively large amount of information concerning housing in Colombia, most of it ignores the complex variety of relationships inherent to human settlements, as well as their permanent evolutions and reconfigurations. Hence, the identification and characterisation of these issues is not an isolated goal, but rather a dynamic process, bound to the formulation and adjustment of policies and projects related to social housing.

For this particular research, the six projects chosen for the sample have shown a series of environmental and structural issues, related to the selection of building materials, the lack of planning and intervention regarding green areas, the design and proportions of the houses and their location and direction in relation to the sunlight. Recent events are symptomatic of these common issues: after the final stages of this research, a social housing project started its development in the west side of the city; after a brief review, it was established that the location and direction 
of the houses in regard to the sunlight was considered and adequately managed; however, several flaws concerning the distribution of space were easily identified.

\section{ACKNOWLEDGEMENTS}

This document is part of the research project Bioclimatic Lab for the Study of Sustainable Social Housing (Laboratorio Bioclimático para el Estudio de Viviendas de Interés Social Sostenible), developed by the research group "City, Environment and Popular Habitat" (Ciudad, Medio Ambiente y Hábitat Popular), endorsed by the Antonio Nariño University (Colombia).

\section{REFERENCES}

Alcaldía de Palmira. (2012). Conozca a Palmira. Available at: http://www. palmira. gov.co/enlaces-de-interes/informacion-general-de-palmira [Accessed on 4 September 2016].

Colombian Ministry of Environment and Territorial Development. (2012). Criterios ambientales para el diseño y construcción de vivienda urbana. Available at: http://www.minambiente.gov.co/images/ AsuntosambientalesySectorialyUrbana/pdf/Sello_ambiental_colombiano/ cartilla_criterios_amb_diseno_construc.pdf [Accessed on 4 September 2016].

Colombian Ministry of Housing. (2014). Colombia: 100 years of housing policies. Available at: http://www.minvivienda.gov.co/Documents/ 100anosdepoliticashabitacionales.pdf [Accessed on 4 September 2016].

Congress of the Republic of Colombia. (2012). Ley 1537: Por la cual se dictan normas tendientes a facilitar y promover el desarrollo urbano y el acceso a la vivienda y se dictan otras disposiciones. Available at: http://www.alcaldiabogota. gov.co/sisjur/normas/Normal.jsp? i=47971 [Accessed on 4 September 2016].

Departamento Administrativo Nacional de Estadística (DANE). (2007). Estimaciones de población 1985-2005 y proyecciones de población 2005-2020 nacional, departamental y municipal por sexo, grupos quinquenales de edad. Available at: http://www.dane.gov.co\%2Files\%2Finvestigaciones \%2Fpoblacion\%2Fseriesp85_20\%2FEstimacionesProyecciones 1985_020. xls\&usg=AFQjCNG5GyDnyHbWBhAH-sxuXWrucrtMig] [Accessed on 4 September 2016].

Escallón. C. (2011). La vivienda de interés social en Colombia, principios y retos. Revista de Ingeniería, 44(1): 55-60.

Gallopin, G. (2003). Sostenibilidad y desarrollo sostenible: Un enfoque sistémico. Santiago de Chile: Cepal.

Garzón, B. (2007). Arquitectura bioclimática. Buenos Aires: Nobuko-Primera.

Gonçalves, H. (2005). Los Edificios Bioclimaticos en los Paises de Ibero América: Livro de Ponencias del Seminario. San Martin de los Andes, Argentina, 31 October - 1 November 2005.

Instituto de Estudios Ambientales Universidad Nacional de Colombia (IDEA). (2002). Propuesta Organizacional: Sistemas de Gestión Ambiental Municipal. Available at: http://www.cortolima.gov.co/SIGAM/home/propuesta.pdf [Accessed on 4 September 2016]. 
Instituto Javeriano de Vivienda de Interés Social (INJAVIU). (2002). Vivienda de interés social, hábitat, y habitabilidad. Bogotá: Pontificia Universidad Javeriana.

Republic of Colombia. (1991). Constitución Política de Colombia. Available at: http://www.corteconstitucional.gov.co/inicio/Constitucion\%20politica\%20 de\%20Colombia\%20-\%202015.pdf [Accessed on 4 September 2016].

Susunaga, J.M. (2014). Construcción sostenible, una alternativa para la edificación de viviendas de interes social y prioritario. Bogotá: Universidad Católica de Colombia.

United Nations General Assembly. (1948). Universal Declaration of Human Rights. Available at: http://www.un.org/en/universal-declaration-human-rights/ [Accessed on 4 September 2016].

United Nations General Assembly. (1996). HABITAT II - Second United Nations Conference on Human Settlements. Available at: http://www.un.org/en/ development/devagenda/habitat.shtml [Accessed on 4 September 2016].

United Nations General Assembly. (1966). International Covenant on Economic, Social and Cultural Rights. Available at: http://www.ohchr.org/EN/ Professionallnterest/Pages/CESCR.aspx [Accessed on 4 September 2016].

Unidad de Planeación Minero Energética (UPME). (2016). Normatividad Ambiental y Sanitaria. Available at: http://www.upme.gov.co [Accessed on 18 December 2016]. 